\title{
APPLE SQUEEZE AND SUGAR BEET MOLASSES APPLICATION FOR YEAST INVERTASE PRODUCTION
}

\author{
Egle Ragauskaite*, Dalia Cizeikiene \\ *Department of Food Science and Technology, Faculty of Chemical Technology, Kaunas University of Technology, Lithuania, \\ e-mail:egle.ragauskaite5@gmail.com
}

\begin{abstract}
Biomass obtained from sugar and apple juice production is rich in nutrients therefore could be reused for microbial fermentation and biologically active compounds production. The aim of research was to apply by-products obtained from food processing, such as sugar beet molasses and apple squeeze for invertase production using yeast strains belonging to Kluyveromyces genus and to evaluate the influence of various factors (temperature, $\mathrm{pH}$ and metal ions) on extracellular invertase production and stability. Invertase production increased by 5.33 and 9.99 times, respectively, using Kluyveromyces marxianus DSM 5422 and Kluyveromyces lactis var. lactis DSM 70799 in molasses medium in comparison with traditional yeast propagation medium (YPD medium made by $10 \mathrm{~g}$ of yeast extract, $20 \mathrm{~g}$ of peptone and $20 \mathrm{~g}$ of glucose). Whereas invertase production increased by 5.91 and 4.40 times, respectively, using K. marxianus DSM 5422 and K. lactis var. lactis DSM 70799 in apple squeeze comparing with traditional YPD medium. The highest activity of invertase was observed at $55{ }^{\circ} \mathrm{C}$ and $\mathrm{pH} 4.5$. Effectors such as $\mathrm{Mg}^{2+}, \mathrm{Ca}^{2+}, \mathrm{Cu}^{2+}, \mathrm{Zn}^{2+}, \mathrm{Na}^{+}$ions significantly decreased invertase activity. The results confirmed that sugar beet molasses and apple squeeze are suitable as nutrients source for invertase producing yeast propagation and invertase production.
\end{abstract}

Keywords: Kluyveromyces, invertase, yeast, sugar beet molasses, apple squeeze

\section{Introduction}

Yeast is widely used in the food industry, especially in the confectionery and beverage industry. Yeasts are rich in proteins, thiamine, riboflavin, niacin, selenium and zinc, vitamins D, C and B group, therefore they are increasingly used as a natural food supplement or even in the cosmetics industry. Yeast has body-building properties: reduces the likelihood of cancer, improves overall well-being of the body, reduces cholesterol, improves digestion, promotes hair growth, strengthens nails and has a positive effect on the skin (Axe, 2015). Yeast (Saccharomyces, Candida, etc.) and bacteria (Bacillus, Escherichia, etc.) produce invertase. Invertase catalyses $\alpha-1,4$ glycosidic linkage between $\alpha$-D-glucose and $\beta$-D-fructose molecules of sucrose by hydrolysis releasing monosaccharides such as glucose and fructose. In yeast, enzyme invertase can be intracellular and extracellular, but extracellular invertase is more economical, easier to purify and more stable (Kulshrestha et al., 2013). Moreover, the same strain of yeast invertase could exist in several forms. For instance, intracellular invertase has a molecular weight of 135000 Daltons, while extracellular invertase has a weight of 270000 Daltons (Nakano et al., 2000). The enzyme is usually purified by ammonium sulphate or gel filtration (Gascon, Lampen, 1968). This enzyme is used in the food industry, especially for inverted sugar production. Invertase catalyses the hydrolysis of sucrose into glucose and fructose mixtures. Enzyme invertase enhances the immune system, helps protect the body from ulcers and other digestive diseases (Group, 2013). It has wide range of commercial applications including the production of confectionery with liquid or soft canters, chocolates, candy products, fondants, after dinner mints, fermentation of cane molasses into ethanol, and production of lactic acid, artificial honey, cosmetics, plasticisers, paper industry and pharmaceuticals (Ilyina et al., 2016; Uma et al., 2012).
The by-products of food processing are increasingly common for the development of sustainable production of bioproducts. By-products help to improve the economy in many industries and protect the environment from pollution. Uma et al. (2010) used fruit peel waste as substrate in the experiment and concluded that it has good potential for biotechnological applications. The enzyme industry can benefit employing molasses for invertase production, due to low enzyme production costs (Veana et al., 2014).

Uma et al. (2010) suggested that metal ions could protect the enzyme against denaturation at high temperature or pH. Enzymatic fixation in a particular phase is an increasingly used method of enzymatic engineering, improving enzyme stability, resistance to various factors and the potential for repeated or continuous use (Mickevičius, 2008). Encapsulation in calcium alginate is a simple and inexpensive invertase immobilization method.

The aim of this work was to evaluate the influence of various factors (temperature, $\mathrm{pH}$, metal ions) on extracellular invertase production and stability.

\section{Materials and Methods \\ Microorganisms cultivation}

Yeast Kluyveromyces marxianus DSM 5422 and Kluyveromyces lactis var. lactis DSM 70799 were purchased from Leibniz Institute DSMZ - German Collection of Microorganisms and Cell Cultures GmbH. Yeast have been propagated using a nutrient broth (Liofilchem, Italy) medium consisting of a $10 \mathrm{~g}$ of yeast extract, $20 \mathrm{~g}$ of peptone and $20 \mathrm{~g}$ of glucose (YPD medium) at $25^{\circ} \mathrm{C}$ for 24 hours and used for further experiment. For solid media preparation, YPD medium supplemented with $18 \mathrm{~g}$ of agar (Liofilchem, Italy) has been used. 


\section{Invertase assay}

Fresh yeast culture after 24 hours of propagation was centrifuged at $10000 \mathrm{rpm}$ for 5 minutes at $4{ }^{\circ} \mathrm{C}$ temperature. The supernatant was used as invertase source for assay. Invertase activity was assayed according to the Sigma-Aldrich protocol (SigmaAldrich). Blank sample was composed of $0.9 \mathrm{~mL}$ of acetate buffer $(100 \mathrm{mM}, \mathrm{pH} 4.5)$ and $0.1 \mathrm{~mL}$ of crude enzyme solution. $0.2 \mathrm{~mL}$ of acetate buffer solution (100 mM, pH 4.5) and $0.8 \mathrm{~mL}$ of sucrose solution were added to the control tube. It was mixed $0.8 \mathrm{~mL}$ of $10 \mathrm{mg}$ $\mathrm{mL}^{-1}$ sucrose as the substrate and $0.1 \mathrm{~mL}$ acetate buffer $(0.1 \mathrm{M} \mathrm{pH} 4.5)$ test the tubes and incubated at $55^{\circ} \mathrm{C}$ for 10 minutes. The reaction was started by addition of $0.1 \mathrm{~mL}$ of crude enzyme solution and test tubes were incubated at $55^{\circ} \mathrm{C}$ for 30 minutes. After enzymatic hydrolysis, a sample of $0.1 \mathrm{~mL}$ was taken from each tube and mixed with $5 \mathrm{mg} \mathrm{mL}^{-1}$ 4-hydroxybenzenkarbohydrazide solution. The mixture was heated in boiling water bath for 5 minutes. After the cooling, the tubes were immediately cooled to reach room temperature. After cooling, $9 \mathrm{~mL}$ of distilled water was added in each tube. The intensity of the colour was read at $410 \mathrm{~nm}$ in UV spectrophotometer (Genesys $10 \mathrm{UV})$. Standard curve was performed with glucose solution. One unit of enzyme activity was defined as the amount of enzyme required for release $1 \mu \mathrm{mol}$ of glucose $\mathrm{mL}^{-1}$ minute $^{-1}$ under assay condition. Enzyme activity was expressed in International units. Invertase activity was calculated using this formula:

$$
U m L^{-1}=\frac{G E V \times P F}{30 \times 0.1 \times 2}
$$

where:

GEV - value of glucose equivalent in a standard curve, $\mu \mathrm{mol}$;

$\mathrm{PF}$ - dilution factor - 10;

30 - time (in minutes) of assay;

0.1 - volume (in millilitres) of crude enzyme;

2 - conversion factor: $1 \mu$ mole of sucrose being hydrolysed to glucose and fructose.

Activity of immobilized invertase was calculated using this formula:

$$
U m g^{-1}=\frac{a}{b}
$$

where:

a - calculated units of enzyme activity per millilitre of reaction mixture, $\mathrm{U} \mathrm{mL}^{-1}$;

$\mathrm{b}$ - mass of immobilized enzyme capsules in reaction mixture, $\mathrm{mg} \mathrm{mL}^{-1}$.

Effect of $p H$ and temperature on invertase activity

Enzymatic hydrolysis was performed at different pH values: 2.5 ; $3.5 ; 4.5 ; 5.5 ; 6.5$ using appropriate buffer at $55^{\circ} \mathrm{C}$. When the effect of temperature was investigated, enzymatic hydrolysis was performed at different temperature: $20^{\circ} \mathrm{C}, 30^{\circ} \mathrm{C}, 40{ }^{\circ} \mathrm{C}, 50^{\circ} \mathrm{C}$, $55^{\circ} \mathrm{C}, 60^{\circ} \mathrm{C}, 70^{\circ} \mathrm{C}, 80^{\circ} \mathrm{C}$ in $0.1 \mathrm{M}$ acetate buffer at $\mathrm{pH}$ 4.5. Invertase activity was determined by the invertase activity assay method described above by performing enzymatic hydrolysis at different $\mathrm{pH}$ values.

\section{Effect of different metal ions on invertase activity}

To evaluate metal ions influence on the enzyme invertase activity various salts as $\mathrm{MgSO}_{4}, \mathrm{CaCl}_{2}$, $\mathrm{CuSO}_{4}, \mathrm{ZnSO}_{4}, \mathrm{NaCl}$ have been added at $0.5 \mathrm{M}$ and enzymatic hydrolysis was performed for 30 minutes at $55^{\circ} \mathrm{C} \mathrm{pH} 4.5$. Invertase activity was determined by the invertase activity assay method described above by performing enzymatic hydrolysis with effectors.

\section{Effect of various carbon source on invertase activity}

The effect of carbon source on the invertase activity was determined by using fructose (Merck, Germany), lactose (Merck, Germany) and various concentrations (10, 20 and $30 \mathrm{~g} \mathrm{~L}^{-1}$ ) of sucrose (Merck, Germany), glucose (Eurochemicals, Lithuania) and various concentrations (20, 40 and $\left.60 \mathrm{~g} \mathrm{~L}^{-1}\right)$ by-products such as molasses and apple squeeze obtained after food processing. Apples were obtained from the supermarket, washed, crushed, squeezed and separated to the juice and the squeezes. $1 \%$ of fresh (72 hours cultivated) K. marxianus DSM 5422 and K. lactis var. lactis DSM 70799 yeast cultures were added. Yeast were grown at $28^{\circ} \mathrm{C}$ in thermostatic shaker $(160 \mathrm{rpm})$ for 72 hours. The activity of the enzyme was measured after 24, 48 and 72 hours of yeast propagation. Invertase activity was determined according to the method described above.

\section{Invertase immobilization}

Yeast cells were immobilized using calcium alginate. $4 \%$ of sodium alginate solution was mixed with crude invertase solution and poured using syringe with a needle into $20 \mathrm{~mL}$ of a $0.25 \mathrm{M} \mathrm{CaCl}_{2} \times 2 \mathrm{H}_{2} \mathrm{O}$ solution, which was slowly stirred in a glass, placed on a magnetic stirrer. After completion of the drip, 30 minutes were allowed to settle. Immobilized enzymes in calcium alginate capsules were washed with distilled water and drained by filtering through filter paper. Measured precise volume of $\mathrm{CaCl}_{2}$ solution. To evaluate the efficiency of immobilization, the invertase activity was measured in initial crude enzyme solution and in $\mathrm{CaCl}_{2}$ solution (including washing water) as described above. Invertase activity was measured in the same manner as before immobilization, but $1 \mathrm{~g}$ of the capsules was taken instead of $0.1 \mathrm{~mL}$ of the crude invertase solution. Invertase activity was calculated using this formula:

$$
\operatorname{IY}(\%)=(1-\mathrm{Y} / \mathrm{X}) \times 100 \%
$$

where:

$$
\mathrm{Y} \text { - remain enzyme activity in } \mathrm{CaCl}_{2} \text { solution after }
$$
immobilization, $\mathrm{U}$;

$\mathrm{X}$ - enzyme activity before immobilization, $\mathrm{U}$.

\section{Results and Discussion}

\section{Effect of $p H$ and temperature on invertase activity}

Invertase activity and stability are influenced by the $\mathrm{pH}$ of the medium, which determines the dissociation of the base and acidic functional groups of the enzyme active site and the remaining parts of the apoferment 
(Mickevičius, 2008). Enzymatic hydrolysis was performed at different $\mathrm{pH}$ values: $2.5 ; 3.5 ; 4.5 ; 5.5 ; 6.5$ (Fig. 1a). Maximum invertase activity of $K$. marxianus DSM 5422 and K. lactis var. lactis DSM 70799 was recorded at $\mathrm{pH}$ 4.5. Aburigal et al. (2014) researched $\mathrm{pH}$ influence on yeast invertase and results showed that the highest invertase activity was found at $\mathrm{pH} 4.5$. The invertase activity of $K$. marxianus DSM 5422 and $K$. lactis DSM 70799 respectively decreased to 60 and $96 \%$ compared with optimal $\mathrm{pH}$ value, at $\mathrm{pH} 4.5$.

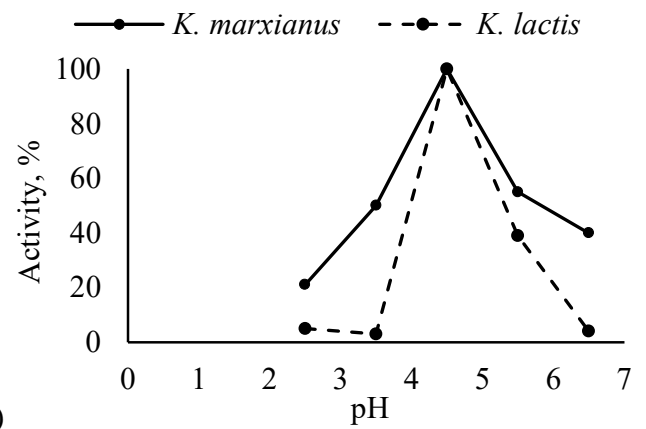

a)

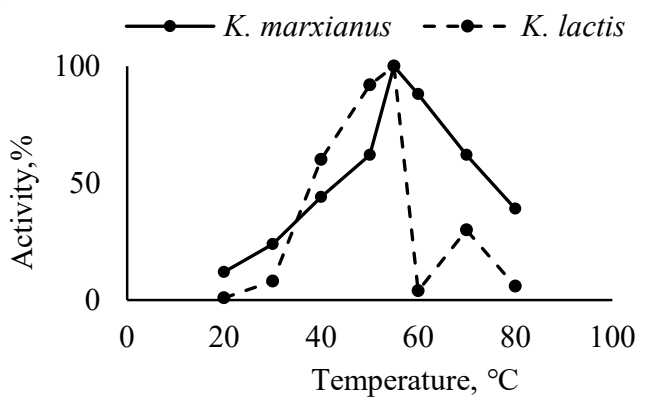

Figure 1. Effect of pH (a) and temperature (b) on invertase activity

Enzymatic hydrolysis was performed at different temperature: $20^{\circ} \mathrm{C}, 30{ }^{\circ} \mathrm{C}, 40{ }^{\circ} \mathrm{C}, 50{ }^{\circ} \mathrm{C}, 55^{\circ} \mathrm{C}, 60{ }^{\circ} \mathrm{C}$, $70{ }^{\circ} \mathrm{C}, 80^{\circ} \mathrm{C}$ in $0.1 \mathrm{M}$ acetate buffer at $\mathrm{pH} 4.5$ for 30 minutes (Fig. 1b). It was determined that optimal temperature for invertase is $55^{\circ} \mathrm{C}$. Kaur and Sharma (2005) also investigated temperature effect on invertase activity and results showed that maximum invertase activity was between $50-60{ }^{\circ} \mathrm{C}$. However, invertase activity significantly decreased at $20^{\circ} \mathrm{C}$ temperature. It can be concluded that as the temperature rises, the reaction rate increases and therefore the activity is higher, but at high temperature hydrogen bonds break off, occur changes in protein conformation, proteins denature, and therefore activity no longer occurs, the reaction is slowing down. At low temperatures, the hydrolysis reaction of the substrate, catalysed by enzymes, occurs slowly (Mickevičius, 2008).

\section{Effect of different metal ions on invertase activity}

The effector investigation was carried out using various metal ions to find out whether the metal ions act as yeast invertase activators or inhibitors. According to literature data, metal ions should protect enzymes from denaturing at high temperatures, but after experimenting at $55^{\circ} \mathrm{C}$ it was observed that metal ions inhibit invertase activity (Uma et al., 2010). Crude enzyme invertase solution was mixed with different metal ions such as $\mathrm{Mg}^{2+}, \mathrm{Ca}^{2+}$, $\mathrm{Cu}^{2+}, \mathrm{Zn}^{2+}, \mathrm{Na}^{+}$for 30 minutes at $55^{\circ} \mathrm{C} \mathrm{pH} 4.5$ (Fig. 2).

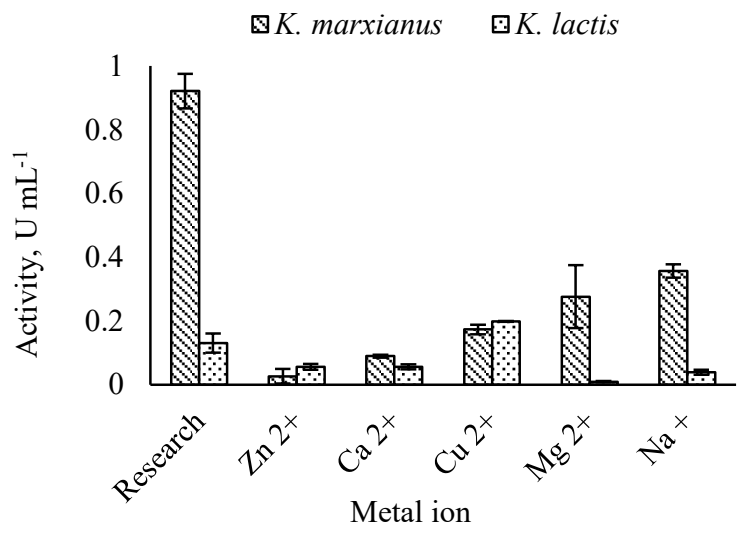

Figure 2. Effect of metal ions on invertase activity

It was found out that all metal ions at used concentrations acted as inhibitors and decreased $K$. marxianus DSM 5422 invertase activity from 100 to 3\%. Meanwhile, K. lactis DSM 70799 invertase activity decreased by $\mathrm{Mg}^{2+}, \mathrm{Ca}^{2+}, \mathrm{Zn}^{2+}, \mathrm{Na}^{+}$, but $\mathrm{Cu}^{2+}$ ions increased invertase activity. Shankar et al. (2013) stated that maximum invertase activity was recorded using calcium chloride for invertase. In Workman and Day (1983) experiment the cations $\mathrm{Hg}^{2+}, \mathrm{Ag}^{+}, \mathrm{Cu}^{2+}$ and $\mathrm{Cd}^{2+}$ exhibited a noticeable inhibition of the enzyme.

Effect of various carbon source on invertase activity

According to the literature, the highest invertase activity was determined using sucrose for yeast production as a carbon source (Uma et al., 2010).

The effect of carbon source on the invertase activity was determined by using various concentrations of sucrose, glucose, fructose, lactose and by-products of food processing such as molasses and apple squeeze.

Crude enzyme activity depended on carbon source (fructose, lactose and different concentrations sucrose and glucose $\left(10 \mathrm{~g} \mathrm{~L}^{-1}, 20 \mathrm{~g} \mathrm{~L}^{-1} ; 30 \mathrm{~g} \mathrm{~L}^{-1}\right)$ also on fermentation duration. Using sucrose as a carbon source invertase had higher activity compared with other sources approximately 1.5 times. $K$. marxianus DSM 5422 yeast had the highest activity using $20 \mathrm{~g} \mathrm{~L}^{-1}$ sucrose as carbon source after 48 hours $\left(0.733 \mathrm{U} \mathrm{mL}^{-1}\right)$, while $K$. lactis var. lactis DSM 70799 yeast invertase was the most active after 48 hours of fermentation using 10 and $20 \mathrm{~g} \mathrm{~L}^{-1}$ sucrose, accordingly 0.264 and $0.271 \mathrm{U} \mathrm{mL}^{-1}$. Invertase activity was decreased using $30 \mathrm{~g} \mathrm{~L}^{-1}$ sucrose (Fig. 3a). Uma et al. (2010) tested sucrose, fructose, glucose and lactose as carbon source and they claimed sucrose gave the best results.

Using lactose as a substrate $K$. marxianus DSM 5422 yeast invertase activity increased during fermentation time, while $K$. lactis DSM 70799 yeast invertase activity decreased (Fig. 3b). Using fructose as a carbon source, K. marxianus DSM 5422 yeast activity decreased from 0.192 to $0.117 \mathrm{U} \mathrm{mL}^{-1}$ after 48 hours, but after 72 hours increased again. 


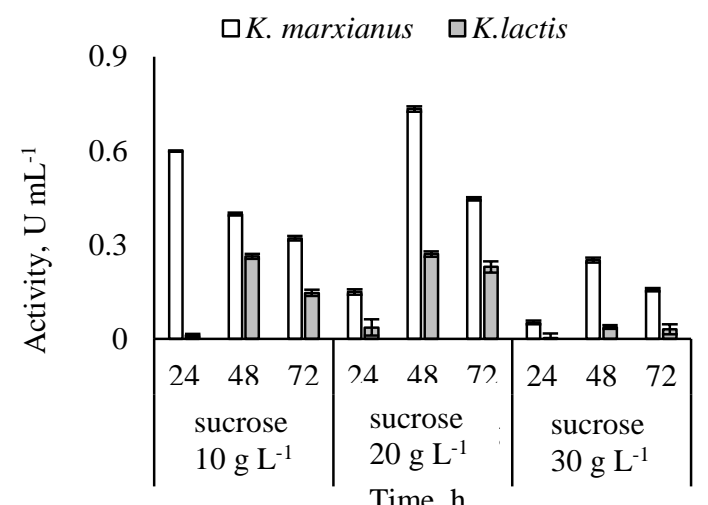

a)

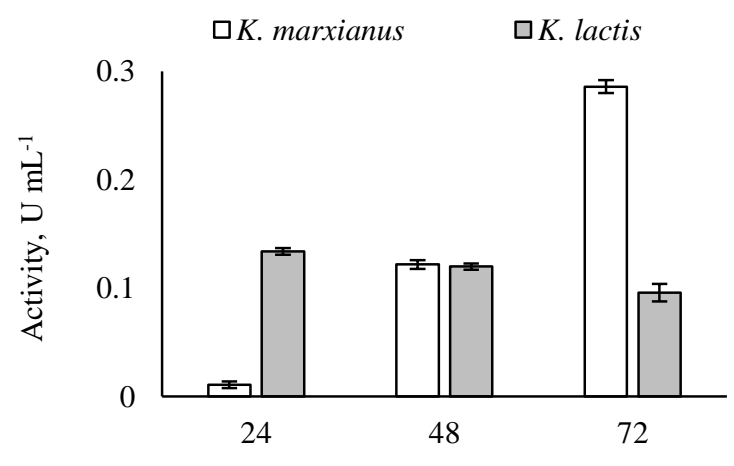

b)

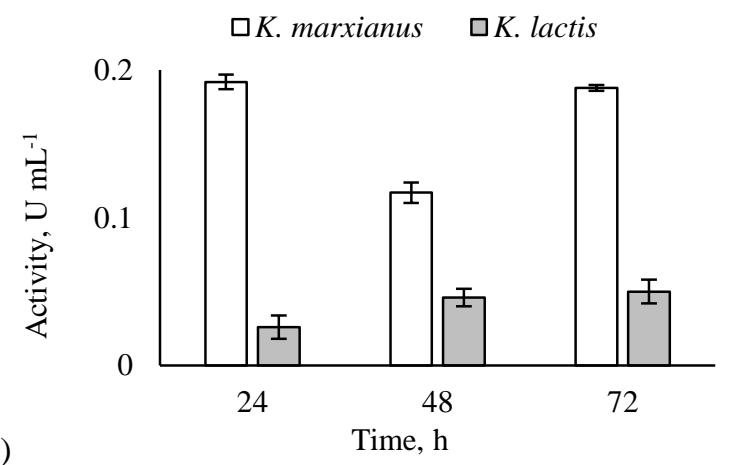

c)

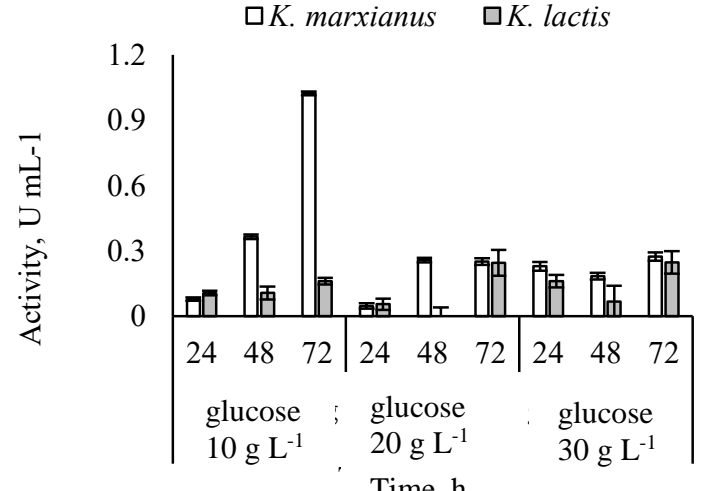

d)

Time, h

Figure 3. Yeast invertase activity by using different carbon sources: a) sucrose; b) lactose; c) fructose; d) glucose
The activity of $K$. lactis DSM 70799 yeast during fermentation grew up to 48 hours and after that remained unchanged (Fig. 3c).

In the evaluation of the effect of glucose as a carbon source on invertase activity, the highest activity of K. marxianus DSM 5422 yeast produced invertase was determined at $1.024 \mathrm{U} \mathrm{mL}^{-1}$ after 72 hours fermentation using $10 \mathrm{~g} \mathrm{~L}^{-1}$ glucose, while using 20 and $30 \mathrm{~g} \mathrm{~L}^{-1}$ glucose, the measured activity was 75 and $73 \%$ lower respectively. The activity of $K$. lactis DSM 70799 yeast invertase was the highest at 20 and $30 \mathrm{~g} \mathrm{~L}^{-1}$ of glucose, respectively of 0.245 and $0.247 \mathrm{U} \mathrm{mL}^{-1}$ after $72 \mathrm{~h}$ of fermentation (Fig. 3d). Vainstein and Peberdy (1991) found out that using glucose as the carbon source invertase activity was the lowest.

Effect of bioproducts as a carbon source on invertase activity

Molasses and apple squeeze contains the most suitable carbon source for K. marxianus DSM 5422 yeast (Fig. 4 $\mathrm{a}$ and $\mathrm{b}$ ). The highest invertase activity of $K$. lactis DSM 70799 yeast was observed using molasses (Fig. 4a).

Molasses is an alternative to sucrose and is increasingly used by industry. Molasses is a suitable substrate for yeast invertase because it has sugars (mainly sucrose), nitrogenous compounds, B group vitamins, macro(phosphorus, magnesium, iron, sulphur) and microelements (zinc, copper) (Taskin, 2016).
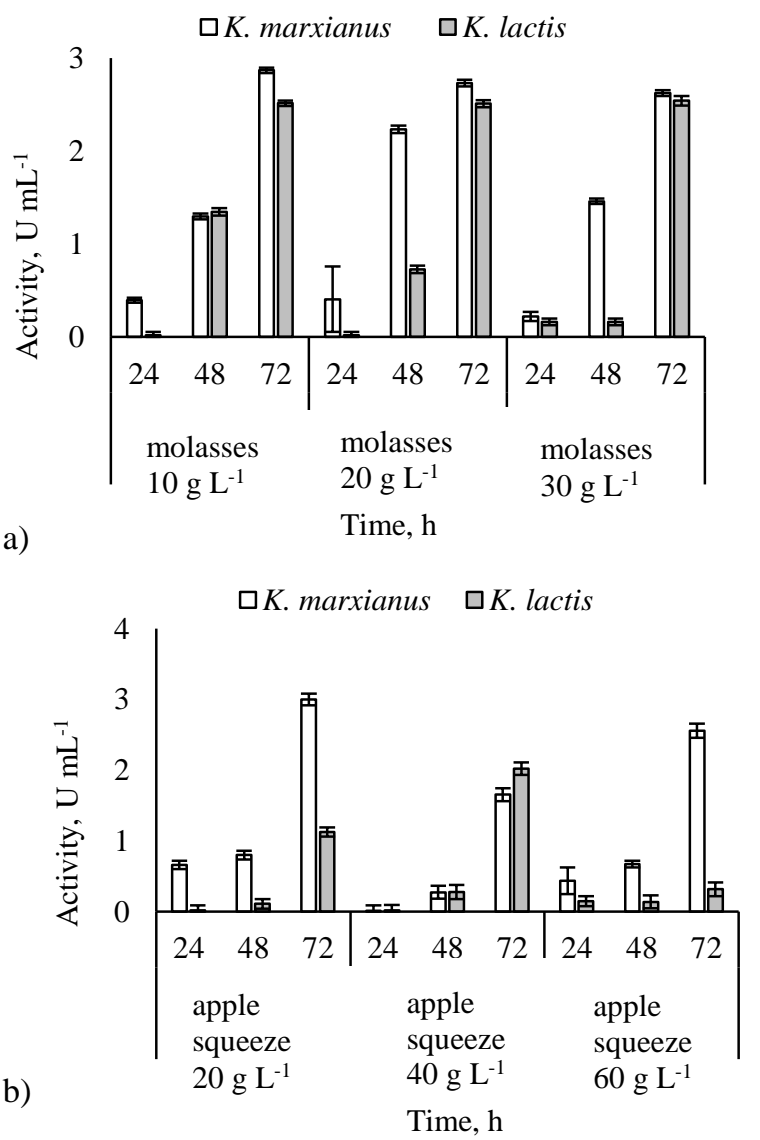

Figure 4. Yeast invertase activity by using different carbon sources: a) molasses; b) apple squeeze 
The study showed a tendency to increase invertase activity during fermentation time. The molasses in the investigated yeast species were a suitable source of carbon - activity of both yeast types reached high values (Fig. 4a). Maximum invertase activity of $K$. marxianus DSM 5422 was detected after 72 hours of fermentation using 10, 20 and $30 \mathrm{~g} \mathrm{~L}^{-1}$ molasses and was on the average $2.74 \mathrm{U} \mathrm{mL}^{-1}$. The highest activity of invertase from $K$. lactis DSM 70799 invertase was also detected after 72 hours of fermentation using both 10, 20 and $30 \mathrm{~g} \mathrm{~L}^{-1}$ molasses (on the average $2.52 \mathrm{U} \mathrm{mL}^{-1}$ ).

The content of the main components in the apple squeeze are: $13 \%$ dry mass, $13 \%$ total sugar, $0.6 \%$ total nitrogen, phosphorus $0.4 \%, 2 \%$ ash (Campeanu et al., 2009). Using apple squeeze as a substrate, the maximum activity of invertase from K. marxianus DSM 5422 was $2.999 \mathrm{U} \mathrm{mL}^{-1}$ after 72 hours of fermentation using

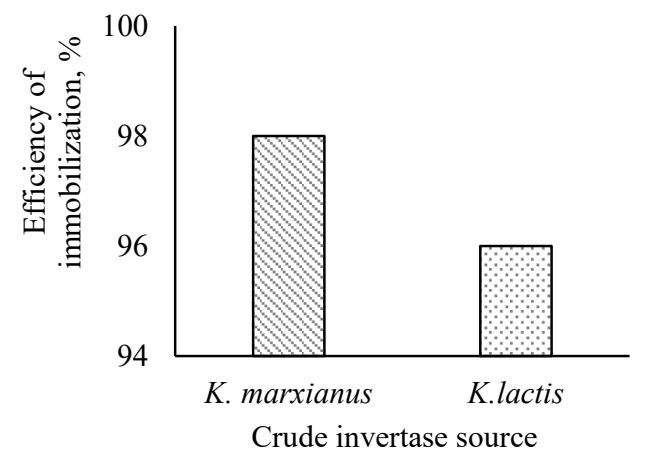

a)

Figure 5. Immobilization efficiency of crude invertase (a) and immobilized invertase activity in calcium alginate capsules (b)

Milovanović et al. (2007) investigated the possibilities of immobilization of invertase, previously obtained from baking yeast, in calcium alginate and also identified very low enzyme losses during this process. Immobilized $K$. marxianus DSM 5422 yeast invertase activity was $0.962 \mathrm{U} \mathrm{g}^{-1}$ and $K$. lactis DSM 70799 was lower $-0.375 \mathrm{U} \mathrm{g}^{-1}$. Although immobilization is a good method to improve the stability and vitality of invertase, Tanriseven and Dogan (2001) found out that invertase after immobilization leaks out of alginate beads and to prevent the leakage of invertase, alginate gel was stabilized by using glutaraldehyde at high $\mathrm{pH}$.

\section{Conclusions}

Effectors such as $\mathrm{Mg}^{2+}, \mathrm{Ca}^{2+}, \mathrm{Cu}^{2+}, \mathrm{Zn}^{2+}, \mathrm{Na}^{+}$ions significantly decreased invertase activity. However, K. lactis DSM 70799 invertase activity was increased by $\mathrm{Cu}^{2+}$ ions. The highest activity of invertase was observed at $55^{\circ} \mathrm{C}$ and $\mathrm{pH}$ 4.5. Meanwhile, strongly acidic $\mathrm{pH}(\mathrm{pH} 2.5)$ and $20^{\circ} \mathrm{C}$ temperature significantly decreased enzyme activity. Using sucrose as a carbon source, the invertase activity was higher compared to other carbon sources (lactose, fructose and glucose) averaged 1.5 times, but invertase activity was 5 times higher using by-products such as molasses and apple squeeze as carbon sources compared to traditional. The
$20 \mathrm{~g} \mathrm{~L}^{-1}$ apple squeeze. The highest activity of $K$. lactis DSM 70799 invertase was after 72 hours fermentation using 20 and $40 \mathrm{~g} \mathrm{~L}^{-1}$ apple squeeze, respectively, 1.127 and $2.021 \mathrm{U} \mathrm{mL}^{-1}$.

By-products obtained from agriculture or food production industries are attractive for the production of bioproducts, because it reduces environmental pollution and boosts the economy (Uma, 2010), and the use of byproducts such as molasses and apple squeeze is relevant to the development of sustainable bio-product production.

\section{Invertase immobilization}

The immobilization efficiency of crude invertase was very high for both $K$. marxianus DSM 5422 and K. lactis DSM 70799 yeast (98 and 96\% respectively) (Fig. 5).

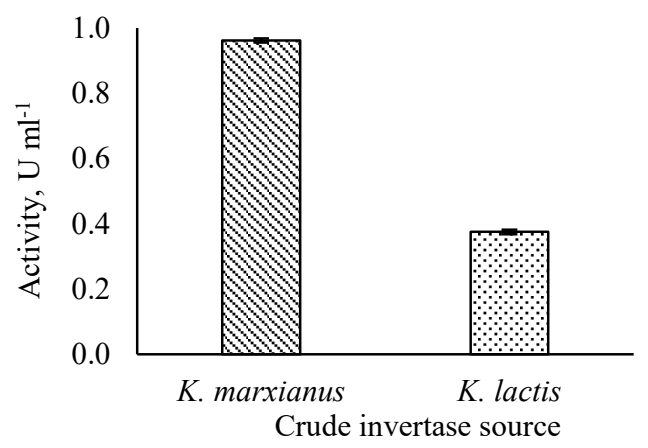

b)

highest activity of $K$. marxianus DSM 5422 yeast invertase was as a nutrient medium for the cultivation of yeast using molasses and apple squeeze, and for $K$. lactis DSM 70799 - molasses. Immobilization of invertase from $K$. marxianus DSM 5422 and K. lactis var. lactis DSM 70799 in calcium alginate gel beads was suitable for enzyme reuse.

\section{References}

1. Aburigal A. A. A., Elkhalifa E. A., Sulieman A. M. E., Elamin H. B. (2014) Extraction and partial kinetic properties of invertase from Schizosaccharomyces pombe. Food Science and Nutrition Engineering, Vol. 4(3), p. 80-85.

2. Axe J. (2015) Nutritional Yeast: The Antiviral, Antibacterial Immune-Booster. [accessed on 7.02.2019]. Available: https://draxe.com/nutritional-yeast/

3. Campeanu G., Neata G., Darjanschi G. (2009) Chemical composition of the fruits of several apple cultivars growth as biological crop. Notulae Botanicae Horti Agrobotanici Cluj-Napoca, Vol. 37(2), p. 161-164.

4. Gascon S., Lampen J. O. (1968) Purification of the internal invertase of yeast. Biological Chemistry, Vol. 243(7), p. 1567-1572.

5. Group E. (2013) The health benefits of invertase. [accessed on 7.02.2019]. Available: https://www.globalhealingcenter.com/naturalhealth/invertase/ 
6. Ilyina A., Ramos-Gonzalez R., Vargas-Segura A., Sanchez-Ramirez J., Palacios-Ponce S. A., MartinezHernandez J. L., Segura-Ceniceros E. P., ContrerasEsquivel J. C., Aguilar-Gonzalez C. N. (2016) Magnetic separation of nanobiostructured systems for innovation of biocatalytic processes in food industry. Novel Approaches of Nanotechnology in Food, Vol. 1, p. 67-96.

7. Kaur N., Sharma A. D. (2005) Production, optimization and characterization of extracellular invertase by an actinomycete strain. Scientific \& Industrial Research, Vol. 64, p. 515-519.

8. Kulshrestha S., Tyagi P., Sindhi V., Yadavilli K. S. (2013) Invertase and its applications - A brief review. Pharmacy Research, Vol. 7, p. 792-797.

9. Mickevičius V. (2008) Biokatalizatoriai organineje sintezèje. Vilnius: Vilniaus pedagoginio universiteto leidykla, p. 46-55.

10. Milovanovic A., Božic N., Vujčic Z. (2007) Cell wall invertase immobilization within calcium alginate beads. Food Chemistry, Vol. 104(1), p. 81-86.

11. Nakano H., Murakami H., Shizuma M., Kiso T., de Araujo TL., Kitahata S. (2000) Transfructosylation of thiol group by beta-fructofuranosidase, Bioscience, Biotechnology and Biochemistry, Vol. 64, p. 1472-1476.

12. Razmovski R., Vučurovic V. (2011) Ethanol production from sugar beet molasses by $S$. cerevisiae entrapped in an alginate-maize stem ground tissue matrix. Enzyme and Microbial Technology, Vol. 48, p. 378-385.

13. Enzymatic Assay of Invertase. [accessed on 7.02.2019]. Available: https://www.sigmaaldrich.com/technicaldocuments/protocols/biology/enzymatic-assay-ofinvertase.html.

14. Shankar T., Thangamathi P., Rama R., Sivakumar T. (2013) Optimization of invertase production using Saccharomyces Cerevisiae MK under varying cultural conditions. Biochemistry and Biophysics, Vol. 1(3), p. $47-56$.

15. Tanriseven A., Dogan S. (2001) Immobilization of invertase within calcium alginate gel capsules. Process Biochemistry, Vo.36, p. 1081-1083.

16. Taskin M., Ortucu S., Unver Y. Tasar O. C., Ozdemir M., Kaymak H. C. (2016) Invertase production and molasses decolourization by cold-adapted filamentous fungus Cladosporium herbarum ER-25 in non-sterile molasses medium. Process Safety and Environmental Protection, Vol. 103, p. 136-143.

17. Uma C., Gomanhi D., Muthulakshmi C., Gopalakrishnan V. K. (2010) Production, purification and characterization of invertase by Aspergillus flavus using fruit peel waste as substrate. Advances in Biological Research, Vol. 4(1), p. 31-36.

18. Uma C., Gomathi D., Ravikumar G., Kalaiselvi M., Palaniswamy M. (2012) Production and properties of invertase from a Cladosporium cladosporioides in $\mathrm{SmF}$ using pomegranate peel waste as substrate. Asian Pacific Journal of Tropical Biomedicine, Vol. 2, p. 605-611.

19. Vainstein M. H., Peberdy J. F. (1991) Regulation of invertase in Aspergillus nidulans: effect of different carbon sources. General Microbiology, Vol. 137, p. 315-321.

20. Veana F., Martínez-Hernández J. L., Aguilar C. N., Rodríguez-Herrera R., Michelena G. (2014) Utilization of molasses and sugar cane bagasse for production of fungal invertase in solid state fermentation using Aspergillus niger GH1. Brazilian Journal of Microbiology, Vol. 45(2), p. 373-377.

21. Workman W. E., Day D. F. (1983) Purification and properties of the $\beta$-fructofuranosidase from Kluyveromyces fragilis. FEBS Letters, Vol. 160, p. 16-20. 